\title{
ENZYME-LINKED IMMUNOSORBENT ASSAY FOR THE DETECTION OF FERMENTATION METABOLITES: AMINOGLYCOSIDE ANTIBIOTICS ${ }^{\dagger}$
}

\author{
RAYMond C. YAO* and David F. MAhONEY \\ The Lilly Research Laboratories, Eli Lilly and Company, \\ Indianapolis, Indiana 46285, U.S.A.
}

(Received for publication August 15, 1984)

\begin{abstract}
A heterogeneous microplate enzyme immunoassay with a sensitivity of $10 \mathrm{pg} / \mathrm{ml}(1 \mathrm{pg} /$ assay) toward gentamicin has been developed for the detection of aminoglycoside antibiotics in fermentation broths. Purified gentamicin antibody was coated onto the surface of the wells of microtiter plates and incubated with gentamicin-alkaline phosphatase conjugate. The amount of enzyme bound to the antibody was quantified by measuring the change in absorbance at $410 \mathrm{~nm}$ after the addition of the substrate, $p$-nitrophenylphosphate. Competitive assays performed by incubating the antibody and enzyme conjugate with various aminoglycosides showed that the antibody probe cross-reacted with all aminoglycosides tested, except neomycins $\mathrm{B}$ and C. No cross-reaction was detected with non-aminoglycoside antibiotics. Complex fermentation broths did not interfere with this assay. Cultures known to produce aminoglycosides were detected at levels well below the concentrations required for antimicrobial activity. This technique is useful in the identification, quantification and screening of fermentation metabolites.
\end{abstract}

Agar diffusion assays using indicator microorganisms have been conventionally used for the detection of antimicrobial activity in fermentation broths. Assays of this type normally require overnight incubation, and results are not available until the next day. Information obtained from this assay as represented by the zone of inhibition indicates only the presence of antimicrobial activity without necessarily providing information about the class of antibiotic detected. As the discovery of new antibiotics becomes more difficult, increased assay sensitivity, shorter assay time, and early indication of antibiotic class would greatly facilitate the discovery process.

We have demonstrated the feasibility of detecting small molecular weight metabolites such as antibiotics in fermentation broths using an enzyme immunoassay. Immunoassays of various types have been widely used in clinical and microbiological laboratories for the detection and quantification of drugs, antibodies and hormones in body fluids ${ }^{1)}$. Such assays provide a high level of sensitivity and specificity. Recently, enzyme-linked immunosorbent assays (ELISA) have been applied to the rapid detection and quantification of mycotoxins such as aflatoxin $B_{1}$, aflatoxin $\mathrm{M}_{1}$, ochratoxin $A$, and $T-2$ toxins in agricultural commodities and clinical specimens ${ }^{2 \sim 5)}$. Using aminoglycoside antibiotics as a model system, we have successfully developed an ELISA for detecting low molecular weight compounds in fermentation broths. This paper describes the development of this assay, the cross-reactivity of the antibody probe used, and the application of this technique to the screening for novel fermentation products.

$\dagger$ This report was presented in part at the 84th Annual Meeting of the American Society for Microbiology, St. Louis, Missouri, March 4 9, 1984 


\section{Experimental}

Medium

Glucose-peptone broth consisted of glucose $1 \%$, black strap molasses $2 \%$, peptone (Bacto) $0.5 \%$ and $\mathrm{CaCO}_{3} 0.2 \%$, pH 6.9 .

Antibacterial Assay

Bacillus subtilis ATCC 6633 grown on yeast - peptone agar was used in agar disc (6 mm) diffusion assay. The agar consisted of peptone (Bacto) $0.6 \%$, yeast extract $0.3 \%$, beef extract $0.15 \%$ and agar $2 \%, \mathrm{pH} 7.2$. Zones of inhibition were recorded after 18 hours of incubation at $37^{\circ} \mathrm{C}$.

\section{Chemicals}

The antibiotic samples used for the investigations were as follows: gentamicin sulfate, chloramphenicol, actidione, sodium novobiocin, kanamycin A sulfate and streptomycin sulfate (commercial, Sigma Chemical Company); tetracycline hydrochloride (commercial, ICN Pharmaceuticals); avoparcin (Lederle Laboratories, Pearl River, N.Y.); ristocetin A, fortimicin B, spectinomycin (Abbott Laboratories, North Chicago, IL); sisomicin (Schering Corp., Bloomfield, N. J.); kanamycins A and B, sorbistin B (Bristol Laboratories, Syracuse, N. Y.); seldomycin (Kyowa Hakko Kogyo, Tokyo, Japan); streptothricin (Upjohn Co., Kalamazoo, MI); butirosin, paromomycin (Warner-Lambert, Parke-Davis, Ann Arbor, MI); validamycin (Takeda Chemical Ind., Osaka, Japan). Globulin-free bovine serum albumin (BSA), used as diluent for the enzyme conjugate, was also obtained from Sigma Chemical Company. Other antibiotics were obtained from Lilly Research Laboratories and other chemicals were commercially available.

\section{Gentamicin Antibody}

Goat antiserum (Miles Laboratories) to gentamicin was purified by $30 \%$ and $45 \%$ ammonium sulfate precipitations ${ }^{\mathrm{e})}$ followed by overnight dialysis at $4^{\circ} \mathrm{C}$ against several changes of $0.04 \mathrm{M}$ sodium phosphate buffer ( $\mathrm{pH}$ 8.0). The dialyzed precipitate was further purified by ion-exchange chromatography on a DEAE-Sephadex A-50 (Pharmacia Fine Chemicals) column equilibrated in the same buffer. Purified gentamicin antibody was eluted from the column by a gradient consisting of sodium phosphate buffer of increasing concentration $(0.04 \sim 1.0 \mathrm{M})$ and $\mathrm{pH}(8.0 \sim 4.4)$. ELISA-active fractions were pooled, concentrated by a stirred cell (Amicon model 402) with a XM100A ultrafilter at $4^{\circ} \mathrm{C}$, and dialyzed overnight at $4^{\circ} \mathrm{C}$ against several changes of phosphate-buffered saline (PBS, pH 7.4) containing $0.1 \%$ sodium azide. This stock antibody solution was stored at $4^{\circ} \mathrm{C}$.

\section{Preparation of Gentamicin-alkaline Phosphatase Conjugate}

Alkaline phosphatase (Sigma, type VII-S) was dialyzed overnight against several changes of PBS at $4^{\circ} \mathrm{C}$, followed by conjugation of enzyme $(5 \mathrm{mg})$ to $30 \mu \mathrm{g}$ of gentamicin utilizing $0.2 \%$ glutaraldehyde $^{7)}$.

Enzyme-linked Immunosorbent Assay

The ELISA procedure was based on a modification of VOLLER et al. ${ }^{7}$. Microtiter plates (Costar 3590) were used as the solid phase. Purified antibody was diluted in coating buffer (sodium carbonate bicarbonate, $\mathrm{pH}$ 9.6) and the wells were sensitized overnight at $4^{\circ} \mathrm{C}$ with $0.2 \mathrm{ml}$ of this dilution. The wells were washed 4 times with PBS containing 0.01\% Tween 20 (PBS-Tween). For antibody titration, gentamicin-alkaline phosphatase conjugate $(1.2 \mathrm{mg}$ protein $/ \mathrm{ml})$ was diluted $(1 / 1,250)$ in PBS containing $0.5 \%(\mathrm{w} / \mathrm{v}) \mathrm{BSA}(\mathrm{PBS}-\mathrm{BSA})$ and $0.2 \mathrm{ml}$ was added to microtiter wells treated and untreated with serial dilutions of antibody. For comparison, an equal concentration of unconjugated enzyme was also added to antibody coated wells. The plates were incubated for 2 hours at $37^{\circ} \mathrm{C}$, washed 4 times in PBSTween, and then reacted for 30 minutes with $0.3 \mathrm{ml}$ of $p$-nitrophenylphosphate substrate solution. The reaction was terminated by the addition of $0.05 \mathrm{ml}$ stopping reagent ( $3 \mathrm{~N}$ sodium hydroxide), and total bound conjugate was determined spectrophotometrically at $410 \mathrm{~nm}$ using a Dynatech MR600 microplate reader.

For the competitive ELISA, $0.1 \mathrm{ml}$ of antibiotic solution in PBS-BSA or fermentation broth was added to wells previously coated with $0.2 \mathrm{ml}$ of $1 / 3,200$ dilution of antibody in coating buffer. This was followed by addition of $0.1 \mathrm{ml}$ of a $1 / 625(1.9 \mu \mathrm{g}$ enzyme protein/ml) dilution of enzyme conjugate in PBS-BSA. Plates were incubated and bound conjugate determined as described above. 
Fig. 1. ELISA titration curve for gentamicin antibody.

Titration performed as described in Experimental section. Symbols: $(\triangle)$ Gentamicin antibody assayed with gentamicin-alkaline phosphatase conjugate; $(O)$ gentamicin antibody assayed with unconjugated enzyme; ( $\square$ ) antibody-free PBS-BSA treated wells assayed with gentamicin-alkaline phosphatase conjugate.

Results represent average of triplicate assays.

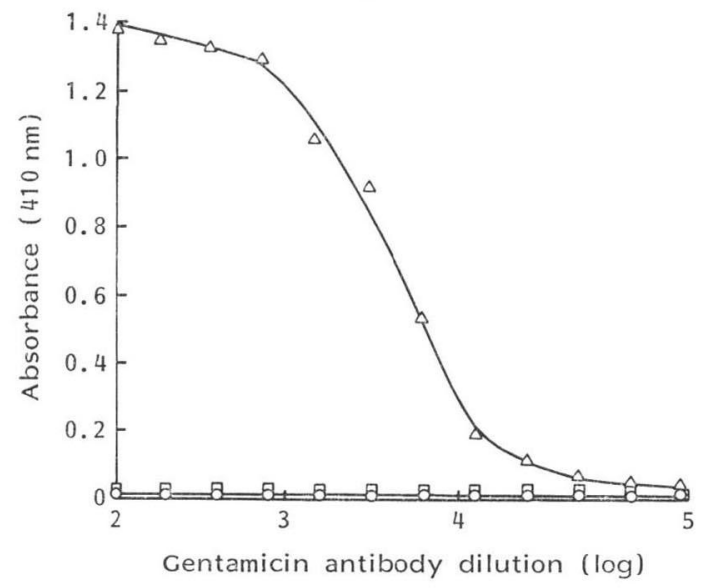

Fig. 2. Determination of optimum antibody concentration for competitive gentamicin ELISA.

Antibody dilutions: (ㅅ) $1: 400 ;(\triangle)$ 1:800; (○) $1: 1,600$; $\square$ ) $1: 3,200$.

$0.1 \mathrm{ml}$ of sample was assayed in each well; $10 \mathrm{pg} /$ assay is equivalent to $100 \mathrm{pg} / \mathrm{ml}$ of sample. Results represent average of triplicate assays.

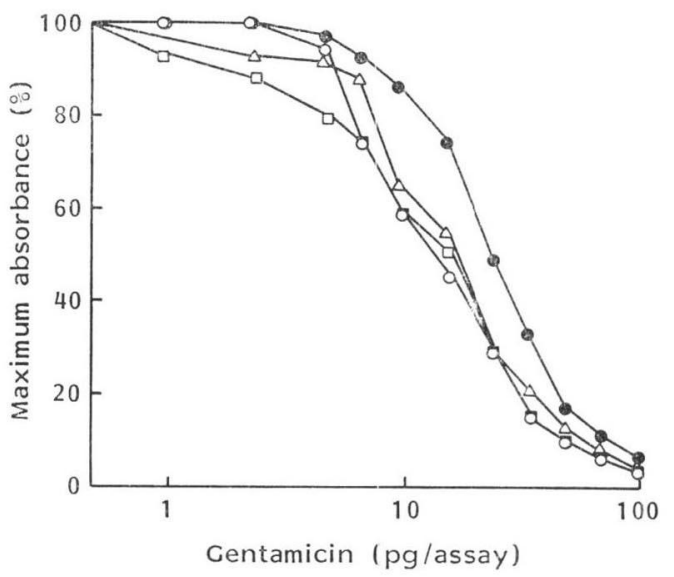

\section{Results and Discussions}

\section{ELISA Titration of Gentamicin Antibody}

To determine the binding capacity of the conjugate for the antibody, an ELISA titration was performed. The first well in the dilution series to yield an absorbance comparable to that of the unconjugated enzyme was considered as the titer end point. The results in Fig. 1 show that the conjugate bound specifically to the antibody with a maximum absorbance of 1.4 at $1 / 100$ dilution and a titer end point of $1 / 100,000$ dilution of the antibody. The unconjugated enzyme, however, showed negligible binding to the antibody as reflected by the low absorbance values. Conjugated enzyme did not bind to the wells in the absence of the antibody. The results suggest that the antibody coating procedure was effective, and the noise to signal ratio of the assay as indicated by the low background was favorable.

\section{Effects of Antibody Dilutions on Competitive Gentamicin ELISA}

To establish the optimal assay conditions for gentamicin detection, it is necessary to determine the antibody dilution which will yield maximum sensitivity and greatest range of detection. The effects of incubating the conjugate with free gentamicin were therefore determined at 4 levels of the antibody (1: $400 ; 1: 800 ; 1: 1,600 ; 1: 3,200$ dilutions), and plotted as a function of percent maximal absorbance (Fig. 2). In a competitive assay, the quantity of bound conjugate to the antibody decreased with increasing concentration of free gentamicin. Significantly reduced absorbance values were produced when compared to a gentamicin-free control set as $100 \%$ maximum absorbance.

Maximal detection range and sensitivity were obtained at 1/3,200 dilution of the antibody, and this concentration was used for further competitive assays. Higher antibody concentrations may require significantly more gentamicin for the displacement of the conjugate, thus decreasing the sensitivity of the 
Table 1. Cross-reactivity of gentamicin antibody with antibiotics in gentamicin ELISA.

\begin{tabular}{lcc|lcc}
\hline \multicolumn{1}{c}{ Antibiotic } & $\begin{array}{c}\text { Zone of } \\
\text { inhibition vs. } \\
\text { B. subtilis (mm)* }\end{array}$ & $\begin{array}{c}\text { Percent } \\
\text { max } \\
\text { OD** }\end{array}$ & Antibiotic & $\begin{array}{c}\text { Zone of } \\
\text { inhibition vs. } \\
\text { B. subtilis (mm)* }\end{array}$ & $\begin{array}{c}\text { Percent } \\
\text { max } \\
\text { OD** }\end{array}$ \\
\hline Benzylpenicillin & 28 & 100 & Monensin & - & 100 \\
Tetracycline & 19 & 100 & Actidione & - & 100 \\
Erythromycin & 32 & 97.9 & Cycloserine & - & 100 \\
Vancomycin & 18 & 100 & Novobiocin & 14 & 100 \\
Avoparcin & 17 & 99.9 & Gentamicin & 20 & $<2.3$ \\
Ristocetin A & 15 & 100 & Streptomycin & 21 & 45.5 \\
Chloramphenicol & 16 & 100 & Control** & - & 100 \\
\hline
\end{tabular}

PBS-BSA solutions spiked with antibiotics and $0.1 \mathrm{ml}$ of sample was assayed in each well. Results represent average of triplicate assays.

* Agar disc $(6 \mathrm{~mm})$ diffusion assay. Concentration of antibiotic; $100 \mu \mathrm{g} / \mathrm{ml}$.

** PBS-BSA used as control was set as $100 \%$ maximum optical density (max OD).

assay. It was also suggested by ENGVAll et $a l .^{8)}$ that at high antibody concentrations the antibody is less efficiently bound and detaches during the incubation process. Since free antibody would compete for the hapten more effectively than the bound antibody, there would be a resultant loss in sensitivity. At 1/3,200 dilution, the most sensitive antibody concentration tested, the detection range of gentamicin was 1 to $100 \mathrm{pg} /$ assay or 10 to $1,000 \mathrm{pg} / \mathrm{ml}$ of sample.

Cross-reactivity of Gentamicin Antibody to Various Classes of Antibiotics

To determine the specificity of this assay, the cross-reactivity of the antibody with different classes of antibiotics was examined with competitive ELISA. Solutions containing antibiotics at 100, 10 and $1 \mu \mathrm{g} / \mathrm{ml}$ in PBS-BSA were assayed, and the results reported at $100 \mu \mathrm{g} / \mathrm{ml}$ are shown in Table 1 . No cross-reactivity of the antibody was detected with the antibiotics tested except the aminoglycosides, gentamicin and streptomycin, indicating that the assay is highly specific.

The cross-reactivity of various aminoglycosides was also examined with this antibody. Utilizing a $90 \%$ maximum absorbance as the cut-off point for positive response, it was found that this antibody cross-reacted in varying degrees with all aminoglycosides tested except neomycins B and C (Table 2). In addition to gentamicin, the antibody exhibited strong cross-reactivity (less than $15 \%$ max OD) against sisomicin, fortimicin $\mathrm{B}$ and seldomycin. Good to moderate cross-reactivity $(15 \sim 50 \% \max$ OD) was achieved against $100 \mu \mathrm{g} / \mathrm{ml}$ solutions of tobramycin, kanamycins $\mathrm{A}$ and $\mathrm{B}$, spectinomycin, apramycin and hygromycin B. Weak cross-reactivity (50 90\% max OD) was observed against $100 \mu \mathrm{g} /$ $\mathrm{ml}$ solutions of butirosin, streptomycin, paromomycin, validamycin A and sorbistin. In most cases, these compounds could be detected below $1 \mu \mathrm{g} / \mathrm{ml}$ level and well below the concentrations required for antimicrobial activity. Streptothricin, a compound structurally related to aminoglycosides, was crossreactive only at $100 \mu \mathrm{g} / \mathrm{ml}$. This antibody was also found to cross-react with semi-synthetic aminoglycosides such as netilmicin (4.0\% max OD), dideoxykanamycin B (37.8\% max OD), amikacin (70.3\% $\max$ OD) and dihydrostreptomycin (78.5\% max OD) at $1 \mu \mathrm{g} / \mathrm{ml}$ levels (results not shown in Table 2).

The results suggest that although the antibody probe used in this assay is highly class-specific, it does offer good cross-reactivity with members of the aminoglycoside family. This antibody, therefore, may serve as an ideal probe for detecting aminoglycoside-producing cultures in fermentation. If, however, quantification and identification of individual members of the aminoglycoside class is desired, a more specific probe may be preferred. For this purpose, the use of a monoclonal antibody which would 
Table 2. Cross-reactivity of gentamicin antibody with aminoglycosides in gentamicin ELISA.

\begin{tabular}{|c|c|c|c|c|c|c|c|c|c|}
\hline $\begin{array}{l}\text { Amino- } \\
\text { glycoside }\end{array}$ & $(\mu \mathrm{g} / \mathrm{ml})$ & $\begin{array}{l}\text { Zone of } \\
\text { inhibition } \\
\text { vs. } \\
\text { B. subtilis } \\
\text { (mm)* }\end{array}$ & $\begin{array}{c}\text { Percent } \\
\max \\
\text { OD** }\end{array}$ & ELISA*** & $\begin{array}{l}\text { Amino- } \\
\text { glycoside }\end{array}$ & $(\mu \mathrm{g} / \mathrm{ml})$ & $\begin{array}{l}\text { Zone of } \\
\text { inhibition } \\
\text { vs. } \\
\text { B. subtilis } \\
\text { (mm)* }\end{array}$ & $\begin{array}{c}\text { Percent } \\
\max \\
\mathrm{OD}^{* *}\end{array}$ & ELISA $^{* * *}$ \\
\hline \multirow[t]{3}{*}{ Gentamicin } & 100 & 18 & 7.1 & + & Hygromycin B & 100 & 12 & 47.8 & + \\
\hline & 10 & 14 & 6.2 & + & & 10 & - & 70.1 & + \\
\hline & 1 & 10 & 5.9 & + & & 1 & - & 74.3 & + \\
\hline \multirow[t]{3}{*}{ Sisomicin } & 100 & 20 & 3.5 & + & Butirosin & 100 & 22 & 59.6 & + \\
\hline & 10 & 15 & 3.5 & + & & 10 & 15 & 70.4 & + \\
\hline & 1 & 11 & 3.5 & + & & 1 & $\mathrm{~T}$ & 67.1 & + \\
\hline \multirow[t]{3}{*}{ Fortimicin B } & 100 & $\mathrm{~T}$ & 4.1 & + & Streptomycin & 100 & 25 & 65.2 & + \\
\hline & 10 & - & 5.3 & + & & 10 & 20 & 79.0 & + \\
\hline & 1 & - & 24.6 & + & & 1 & 10 & 87.7 & + \\
\hline \multirow[t]{3}{*}{ Seldomycin } & 100 & 20 & 11.5 & + & Paromomycin & 100 & 19 & 72.5 & + \\
\hline & 10 & 14 & 42.1 & + & & 10 & 15 & 74.0 & + \\
\hline & 1 & $\mathrm{~T}$ & 62.8 & + & & 1 & $\mathrm{~T}$ & 76.4 & + \\
\hline \multirow[t]{3}{*}{ Tobramycin } & 100 & 19 & 18.2 & + & Validamycin A & 100 & - & 73.6 & + \\
\hline & 10 & 15 & 32.2 & + & & 10 & - & 75.3 & + \\
\hline & 1 & 10 & 52.5 & + & & 1 & - & 78.9 & + \\
\hline \multirow[t]{3}{*}{ Kanamycin A } & 100 & 23 & 17.8 & + & Sorbistin B & 100 & - & 76.7 & + \\
\hline & 10 & 16 & 34.3 & + & & 10 & - & 76.2 & + \\
\hline & 1 & 11 & 52.8 & + & & 1 & - & 76.6 & + \\
\hline \multirow[t]{3}{*}{ Kanamycin B } & 100 & 22 & 19.0 & + & Streptothricin & 100 & 12 & 53.3 & + \\
\hline & 10 & 15 & 32.2 & + & & 10 & $\mathrm{~T}$ & 91.0 & - \\
\hline & 1 & 10 & 50.1 & + & Neomycins & 100 & 14 & 97.5 & - \\
\hline \multirow[t]{3}{*}{ Spectinomycin } & 100 & 12 & 42.6 & + & $B$ and $C$ & & & & \\
\hline & 10 & - & 68.0 & + & Control** & - & - & 100 & - \\
\hline & 1 & - & 78.2 & + & & & & & \\
\hline \multirow[t]{3}{*}{ Apramycin } & 100 & 22 & 43.0 & + & & & & & \\
\hline & 10 & 16 & 62.5 & + & & & & & \\
\hline & 1 & $\mathrm{~T}$ & 77.8 & + & & & & & \\
\hline
\end{tabular}

PBS-BSA solutions spiked with aminoglycosides and $0.1 \mathrm{ml}$ of sample was assayed in each well. Aminoglycosides are listed in descending order of cross-reactivity. Results represent average of triplicate assays.

* Agar disc $(6 \mathrm{~mm})$ diffusion assay. T: Trace.

** PBS-BSA used as control was set as $100 \%$ maximum optical density (max OD).

*** ELISA response: $90 \sim 100 \%=-$ (negative), $<90 \%=+$ (positive).

provide for greater specificity should be considered.

\section{Effects of Fermentation Media on Gentamicin ELISA}

To establish whether organic constituents in fermentation broth interfere with the assay, a competitive ELISA was performed on both uninoculated glucose - peptone broth and PBS-BSA solution spiked with gentamicin at various concentrations. As indicated by the dose-response curves (Fig. 3), no significant difference in assay kinetics was observed between gentamicin-spiked broth or PBS-BSA suggesting that this fermentation medium does not interfere with the assay. Similar results were also obtained with other complex fermentation media (unpublished data).

Since this is a solid phase heterogeneous assay, in which the unreacted conjugate and other interferring materials are washed off from the solid support, interference and background of the assay are minimized. Therefore, only the conjugate retained on the surface of the well contributed to the final reading. The addition of $0.5 \% \mathrm{BSA}$ to the gentamicin-enzyme conjugate in PBS also greatly reduced 
non-specific binding, thus providing a low assay background.

Detection of Aminoglycoside-producing Cultures in Fermentation

To determine if this assay is capable of detecting cultures producing aminoglycoside antibiotics, reference organisms known to produce aminoglycosides were grown in glucose - peptone broth. Results (Table 3) from these studies indicated that gentamicin and sisomicin producers, as expected, yielded strong positive responses. Fortimicin and kanamycin producers were detected despite their poor antimicrobial activity. A good positive response was also observed with streptomycin- and paromomycinproducing cultures. Although pure neomycins $\mathrm{B}$ and $\mathrm{C}$ did not yield a positive response in our
Fig. 3. Effects of glucose - peptone broth on competitive gentamicin ELISA.

Uninoculated glucose-peptone broth $($ ) and PBSBSA $(\triangle)$ solution were spiked with gentamicin at various concentrations and assayed. Results represent average of triplicate assays.

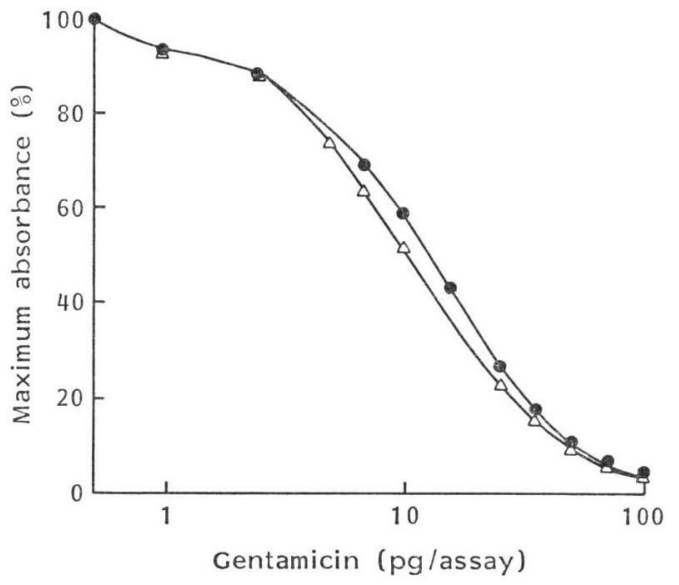
cross-reactivity studies, this particular neomycin producer exhibited a positive reaction in this assay. It is highly possible that this culture was producing multiple factors of neomycin such as neomycins $\mathrm{E}$ and $\mathrm{F}$ also known as paromomycins I and II, respectively ${ }^{9}$. Paromomycin was shown to elicit a positive response (Table 2) with this antibody. A negative response, however, was observed with a weak streptothricin-producer.

Since the antibody is directed towards gentamicin, it is obvious that gentamicin, and its structural analog sisomicin, gave a strong positive response as indicated by the nearly total displacement of the enzyme conjugate. This antibody may be used for the quantification of gentamicin, sisomicin and

Table 3. Detection of aminoglycoside-producing cultures in fermentation.

\begin{tabular}{|c|c|c|c|c|c|}
\hline \multicolumn{2}{|c|}{ Organism* } & \multirow{2}{*}{$\begin{array}{c}\text { ATCC } \\
\text { No. }\end{array}$} & \multirow{2}{*}{$\begin{array}{l}\text { Antibiotic } \\
\text { Gentamicin }\end{array}$} & \multirow{2}{*}{$\begin{array}{c}\begin{array}{c}\text { Zone of inhibition } \\
\text { vs. B. subtilis } \\
\text { (mm) }\end{array} \\
14\end{array}$} & \multirow{2}{*}{$\begin{array}{c}\begin{array}{c}\text { Percent } \\
\max \mathrm{OD}^{* *}\end{array} \\
<1\end{array}$} \\
\hline Micromonospora sp. & M. echinospora & & & & \\
\hline & M. purpurea & 15835 & Gentamicin & 17 & $<1$ \\
\hline & M. inyoensis & $3292 * * *$ & Sisomicin & 13 & $<1$ \\
\hline & M. olivoasterospora & 21819 & Fortimicin & - & 37 \\
\hline \multirow[t]{7}{*}{ Streptomyces sp. } & S. albogriseolus & 23875 & Neomycin & 11 & 53 \\
\hline & S. kanamyceticus & 12853 & Kanamycin & trace & 45 \\
\hline & S. rimosus & 14827 & Paromomycin & 21 & 60 \\
\hline & S. bikiniensis & 11062 & Streptomycin & 22 & 50 \\
\hline & S. griseus & 10137 & Streptomycin & 11 & 40 \\
\hline & S. lavendulae & 19777 & Streptothricin & trace & 100 \\
\hline & Control (broth)** & & & & 100 \\
\hline
\end{tabular}

* Cultures were grown in 250 - $\mathrm{ml}$ flasks each containing $50 \mathrm{ml}$ glucose - peptone broth for 4 days, at $30^{\circ} \mathrm{C}$ and $250 \mathrm{rpm}$. $0.1 \mathrm{ml}$ of broth was assayed in each well. Results represent average of triplicate assays.

** Uninoculated glucose - peptone broth used as control was set at $100 \%$ maximum optical density (max OD). 
fortimicin B which have shown good reactivity or strong affinity for the antibody.

In conclusion, we have demonstrated the feasibility of using an enzyme immunoassay to detect the production of fermentation metabolites. The determination of low molecular weight compounds by enzyme immunoassay can only be done by competitive bin ing assays since these haptens generally lack two binding sites to which antibodies can bind without interference ${ }^{10)}$. The polyclonal antibody used in this assay offered high specificity in detecting only aminoglycoside-related antibiotics and, at the same time, provided good cross-reactivity among members of this family. These assays, by nature of their specificity and sensitivity, lend themselves to the identification and, if desired, early elimination of antibiotics of a specific class. Fermentation metabolites may be quantified with more sensitivity and precision than by conventional antimicrobial assays. This type of assay is especially useful in strain improvement and fermentation scale-up studies. Finally, due to the type of automated equipment available commercially, this technique is amenable for high volume screening and detection of fermentation metabolites.

Acknowledgments

We thank Dr. R. S. Baker, Dr. B. H. Petersen and M. Heim for use of their equipment, technical assistance and valuable discussions in the initial stages of this work. We gratefully acknowledge the assistance of Mrs. L. W. CRANDALl for her critical reading of this manuscript.

\section{References}

1) Schuurs, A. H. W. M. \& B. K. Van Weemen: Enzyme-immunoassay. Clin. Chem. Acta 81: 1 40, 1977

2) Lawellin, D. W.; D. W. Grant \& B. K. Joyce: Enzyme-linked immunosorbent analysis for aflatoxin $B_{1}$. Appl. Environ. Microbiol. 34: 94 96, 1977

3) Pestka, J. J.; Y. Li, W. O. Harder \& F. S. Chu: Comparison of radioimmunoassay and enzyme-linked immunosorbent assay for determining aflatoxin $\mathrm{M}_{1}$ in milk. J. Assoc. Off. Anal. Chem. 64: 294 301, 1981

4) Pestka, J. J.; S. C. Lee, H. P. LaU \& F. S. Chu: Enzyme-linked immunosorbent assay for T-2 toxin. J. Am. Oil Chem. Soc. 58: 940A 944A, 1981

5) Peskta, J. J.; B. W. Steinert \& F. S. Chu: Enzyme-linked immunosorbent assay for detection of ochratoxin A. Appl. Environ. Microbiol. $41: 1472 \sim 1474,1981$

6) Hebert, G. A.; P. L. Pelham \& B. Pittman: Determination of optimal ammonium sulfate concentration for the fractionation of rabbit, sheep, horse, and goat antisera. Appl. Microbiol. 25: 26 36, 1973

7) Voller, A.; D. E. Bidwell \& A. Barlett: Enzyme immunoassays in diagnostic medicine: Theory and practice. Bull. World Health Organ. 53: 55 65, 1976

8) Engvall, E. K.; K. Johnson \& P. Perlman: Enzyme-linked immunosorbent assay of protein antigen, immunoglobulin $\mathrm{G}$, by means of enzyme-labelled antigen and antibody coated tubes. Biochim. Biophys. Acta $251: 427 \sim 434,1971$

9) Glasby, J. S. (Ed.): Encyclopedia of Antibiotics. 2nd Ed. p. 324, John Wiley and Sons Ltd., 1979

10) Amshey, J. W.: Enzyme immunoassay. In Annual Reports in Medicinal Chemistry. Vol. 18, Ed., H.-J. Hess, pp. 258 292, Academic Press, New York, 1983 